\title{
Excess Land Law: Calculated Circumvention
}

\author{
Paul S. Taylor*
}

TEDERAL ReClamation began as a program to help "farm boys" who I "want farms of their own" obtain them "without being driven into the already overcrowded cities to seek employment." Begun as a turnof-the-century "war on poverty," reclamation is administered currently on important projects in apparent forgetfulness of this purpose. ${ }^{2}$ On these projects it has become a program largely to subsidize reclamation of great landholdings primarily for the benefit of their owners. This Article is a study of current circumvention of the antimonopoly provisions of reclamation law in two areas within the Central Valley Project. ${ }^{3}$

The study concerns contracts between the United States and the Westlands Water District, a portion of the Federal Service Area of the San Luis Unit which, in turn, is a portion of the Great Central Valley Project. The Westlands District is located on the west side of California's San Joaquin Valley. The pattern of circumvention with which this Article deals is also evidenced by the contract between the United States and the Glenn-Colusa Irrigation District regarding diversion of water from the Sacramento River.

At Westlands, a half-million privately owned acres threatened with return to "sagebrush" and "desert" are currently under federal reclamation at an authorized cost to the public of nearly a half-bilhion dollars. There, the antimonopoly excess land laws are being violated wholesale. An excuse for the violation has already been arranged.

At Glenn-Colusa, the same antimonopoly excess lands laws are being frustrated. The means of frustration may be different, but the circum-

* Professor of Economics, Emeritus, University of California, Berkeley; consultant to the Office of the Secretary of the Interior and Bureau of Reclamation 1943-52. Letters and various other cited docunents not otherwise available to the public are being filed under the title of this Article at the Bancroft Library, University of California, Berkeley, and are indicated lerein by an asterisk (*).

1 Congressman Oscar W. Underwood, of Alabama. S. Doc. No. 446, 57th Cong., 1st Sess. 21 (1902).

2 Secretary of the Interior Stewart $\mathrm{L}$. Udall listed his Department's contributions toward the "war on poverty" in testimony on the Economic Opportunity Bill in April 1964. He spoke of assistance to Indians and employment opportunities for youth on public lands, but failed to mention the vast Bureau of Reclamation program. Hearings on H.R. 10440 Before House Subcommittee on War On Poverty of Committee on Education and Labor, 88th Cong., 2d Sess. 341-61 (1964).

3 Present administrators of the Department of the Interior failed also to require observance of the excess land law in the contract between the United States and the State of California after Congress bad denied exemption. See notc 30 infra. 
vention is no less conspicuous. ${ }^{4}$ Circumvention in the Federal Service Area and along the Sacramento, however, have this in common: No challenge to national antimonopoly policy lias been raised or deliberated in Congress; no word of any statute has been altered.

\section{I}

\section{ANTIMONOPOLY POLICY: THE EXCESS LAND LAW}

The purpose of the federal reclamation program, launched by Congress in $1902,{ }^{5}$ is to provide national assistance to develop the water resources of the West. Its principal financial instrument is a subsidy from the national treasury in the form of long-term interest-free loans. The value of this subsidy to beneficiaries is substantial, roughly equal to the amount of the investment itself. In addition, there are other large subsidies from power users, municipalities, and taxpayers that reduce the cost of water to irrigators. ${ }^{6}$ As originally presented to Congress and the courts, the main justifications for undertaking federal reclamation are two-fold: (1) it promotes national development in the West; and (2) its benefits are distributed widely among the many, and are not monopolized by the few. ${ }^{7}$ In the words of Theodore Roosevelt, who inspired the excess land provisions and first signed reclamation into law, "every dollar is spent to build up the small man of the West and prevent the big man, East or West, coming in and monopolizing the water and land."s

The legal instrument for effectuating the antimonopoly policy of the reclamation law is the excess land provisions. By the origmal Reclamation Act, "no right to the use of water for land in private ownership shall be sold for a tract exceeding one hundred and sixty acres to any one landowner . . . ." It slould be noted that this provision limits the size of ownership of land entitled to receive water, not the scale of operations. $^{10}$

\footnotetext{
4 Letter From Martin H. Blote to Secretary of the Interior Udall, January 30, 1964 (*) [hereinafter cited as Blote to Udall].

544 Stat. 649, 650 (1926), 43 U.S.C. \& 391 (1958).

B See, e.g., Note, 38 Carif. L. Rev. 728, 730-32 (1950).

7 See House Committee on Arid Lands, Report on Reclamation and Arid Lands, H.R. Rep. No. 1468, 57th Cong., 1st Sess. 3 (1902); Burley v. United States, 179 Fed. 1, 7-8 (1910).

8 Theodore Roosevert, 7 Transactions of the Comamonwealth Club 102 (1912-13). 044 Stat. 649 (1926), 43 U.S.C. $\$ 431$ (1958).

$10 \mathrm{~A}$ spokesman for large landholding interests of California asserted that "[T]he excess land provisions apply only to the record ownership of land. There is no statutory limitation on the amount of land that may be leased and farmed under the projects." S. T. Harding, Hearings on S. Res. 295 Before Senate Subcommittee on Irrigation and Reclamation, 78th Cong., 2d Sess. 358 (1944) [hereinafter cited as 1944 Hearings on S. Res. 295]. Opponents of the excess land law also have taken an opposite view in arguing against the excess land law; e.g., "We sincerely feel that such a limitation, if imposed, . . . would . . f fail to recog-
} 
In 1924 a special advisory committee issued what has come to be known as the Fact Finders Report, recommending revisions of reclamation law. ${ }^{11}$ The main purpose of reclamation was reiterated: "to provide opportunities for hoinestead making for rural-minded people. Making a homestead, a place able to support a family and desirable for family life, must remain the central thought of . . Federal reclamation."12

The Fact Finders' proposals for revision were intended: (1) to simplify Federal administration of projects by giving water users a larger sense of participation and responsibility througl their own organizations; ${ }^{13}$ (2) to strengthen controls over private speculation, which had "added greatly to the farner's burdens" in seeking to win his "homestead from the desert;" $" 14$ and (3) to assure more effective enforcement of the excess land provision by requiring that "no reclamation project should hereafter be authorized until all privately owned land in excess of a single hoinestead unit for eacl owner shall have been acquired by the United States or by contract placed under control of the Bureau of Reclamation ....."15

These suggested revisions were influential in the rewriting of reclamation law two years later when Congress passed the Omnibus Adjustinent Act. ${ }^{16}$ It prescribed execution of contracts between the Secretary of the Interior and irrigation districts prior to water deliveries to new projects, and thus provided the needed "sense of participation."17 It established new controls over private speculation. Water rights were denied to otherwise eligible lands if they were created by subdivision of ineligible excess lands, unless the subdivided lands were sold at a price appraised "without reference to the proposed construction" of the project. ${ }^{18}$ Most important, the act tightened the language of the excess land

nize the startling agricultural trends of the past several decades which have shifted farming away from family type operations on small plots to the mass production science necessary to feed and clothe the rising population." D. B. McHenrx, Heardnc Before Cartrorania Assearbiy Comaurtree on Water (1959). See also Los Angeles Times, June 7, 1964, p. 6-G, col. 1.

11 Report by the Committee of Special Advisers on Reclamation, S. Doc. No. 22, 68th Cong., 1st Sess. (1924).

12 Id. at 111 .

13 Id. at 103-08.

14 Id. at 114-16.

15 Id. at 116. This recommendation applies to the Secretary of the Interior to whom it was made, and to Congress. Congress chose to adopt this recommendation for at least one project, leaving it otherwise within administrative discretion. Leaving this discretion to the Secretary has exposed him to severe pressures from large landholders to exercise his discretion in their favor, rather than to create more opportunity for small farmers' families. See text accompanying notes 107-13 infra.

18 44. Stat. 636 (1926), 43 U.S.C. $\$ 423$ (1958).

1744 Stat. 649 (1926), 43 U.S.C. \$ 423 (e) (1958).

18 Ibid. 
provision, and added a device to facilitate effective enforcement. Reclamation law now prohibits not only the sale of a water right, but also forbids excess lands from receiving project water unless the owner authorizes the Government to sell these lands. ${ }^{19}$

The Act of 1926 also reduced the financial obligations of settlers on many reclamation projects, an evidence of more congressional concern for effectuating the policies of the Reclamation Program than for recovery of costs. Under the Act, repayment of the federal investment by beneficiaries, without interest, is accomplished through contracts executed between the Umited States and organized water users' districts having power to raise revenue. Although these contracts customarily recite the duty of the district to observe the excess land law, this recitation does not of itself enforce the law. More is required, and it is provided for in the 1926 Oinnibus Act. ${ }^{20}$

The enforcement device created by this Act provides that the only way landowners can render their excess lands eligible to receive reclamation project water is by individually executing recordable contracts with the United States. These contracts, executed in return for the right to receive subsidized water, authorize the Secretary of the Interior to sell lands in excess of 160 acres, at appraised prices excluding imcremental values added by the proposed construction of the irrigation works.

The statute imposes a clear and unqualified requirement that "no such excess lands so held shall receive water from any project or division if the owners thereof shall refuse to execute valid recordable contracts for the sale of such lands under terms and conditions satisfactory to the Secretary of the Interior . . . ."21

\section{II}

RECLAMATION ISSUE AT SAN IUIS: ADMINISTRATION

San Luis is but the most recent in a long succession of units authorized by Congress under reclamation law as part of federal development of the Central Valley's water resources. ${ }^{22}$ Although dispute over application of the excess land law has come sharply into focus at San Luis, division over the question did not originate there. Because of the existence of large western landholdings, antimonopoly pohicy has been a prominent issue in federal reclamation from its legislative beginnings. ${ }^{23}$ Nowhere has the

19 Ibid.

20 Ibid.

21 Ibid.

22 See Central Valley Basin: A Comprehensive Departmental Report on the Development of the Water and Related Resources of the Central Valley Basin, and Comments from the State of California and Federal Agencies, S. Doc. No. 113, 81st Cong., 1st Sess. (1949). 23 See Taylor, Central Valley Project: Water and Land, 2 W. Por. Q. 229, 238-45 (1949). 
issue been the object of more heated or more protracted debate than in the Great Central Valley of California. The greatest concentration of ownerslip of irrigable lands in the United States is there, especially in the San Joaquin Valley of which the Federal San Luis Service Area ${ }^{24}$ is a part.

Seventy percent of the lands of the Federal San Luis Service Area are inehgible under the excess land law to receive project water because they are held in ownerships exceeding 160 acres and their owners have not executed recordable contracts to make them eligible. A single owner, the Southern Pacific, holds nearly 120,000 acres. Other holdings are also very large; $m$ all about 250,000 acres of the Federal Area are owned in excess amounts. ${ }^{25}$

In pleading initially for congressional authorization of the 483 million dollar San Luis Project, spokesmen in the House and Senate portrayed the dire need for water of all the people in the Federal Service Area, and of all the lands. Congressman B. F. Sisk, of California, described the bleak future facing the 10,500 rural people and 12,500 townspeople who "will have to leave and seek livings and hoines elsewhere, ... starved out of existence by lack of water." "Most of the cultivated land which is the basis of their economy," he said, "will revert to desert."20 Senator Clair Engle, of California, spoke of ground waters being " 'mined' to the point of exhaustion" by pumping; of "consuming a capital resource"; and of the necessity of appealing for a federal " 'rescue' project" to "save good cropland from returning to sagebrush and sand."27

As discussion of the San Luis authorization bill proceeded in Congress, it developed that winning support for financing the project depended more on allaying doubts that the excess land law actually would be applied, than upon the distressed appeals to rescue the land from return to "sagebrush and sand."28 These doubts concerned two land areas of the project, and two branches of the federal government. The first con-

24 Lands served directly by the federally-administered project are designated as Federal Service Area; those served directly by the State-administered project are called State Service Area. Both federal and state projects use "joint facilities" including reservoir, canals, and pumps.

25 Assistant Secretary of the Interior Kenneth Holum, Hearing Before Senate Commiltee on Interior and Insular Affairs ... on Proposed Contract Between the Secretary of the Interior and Westlands Water District for Construction of a Water Distribution and Drainage Collector System in the San Luis Unit, Central Valley Project, California, 88th Cong., 2d Sess. (July 8, 1964) [hereinafter cited as 1964 Westlands Hearing]. See also testimony of Taylor, 1964 Westlonds Hearing at 140.

26 Hearings on H.R. 301 Before House Subcommittee on Irrigation and Reclamation, 86th Cong., 1st Sess. 13 (1959).

27105 Cong. REc. 7485 (1959).

28 See 105 Cong. Rec. 8001 (1959). 
cern was application of the excess land law to the so-called State Service Area. ${ }^{20}$ The bill authorized joint use of the San Luis facilities not only for the Federal Service Area, but also by the State of California, and proposed legislative exemption of the State Service Area. The Senate debated the proposed exemption for four days, and the House for two. Both bodies refused legislative exemption. ${ }^{30}$ There was no attempt to gain exemption of the excess land law for the Federal Service Area.

The second concern of Congress was whether the executive branch of Government could be relied on to enforce the excess land provision in eitlier the State or Federal Service Area. The record of nonenforcement was long, ${ }^{31}$ and pressures from excess landholding interests to prevent executive enforcement had been unremitting.

As early as 1944 State Engineer Edward Hyatt, speaking for the California Water Project Authority, told Congress that exemption of the Central Valley Project was "expected," if not by legislative decision, then by executive action. ${ }^{32}$ Three years later he testified that the State Authority was in sympathy with "the vast inajority of the people who are affected," i.e., the excess landowners, and pronounced the law "unjust and harsli and unworkable."33

Legislators friendly to the excess land provision expressed deep distrust of the executive during debate on the San Luis authorization bill. Democratic Senator Wayne Morse, of Oregon, said he was "sure that the Secretary of the Interior" of the current Republican Administration, "given the wide range of authority to negotiate agreements ... will

28 See note 24 supra.

30 See 105 Cong. Rec. 7483-98, 7665-91, 7849-77, 7986-8000 (1959); 106 Cong. Rec. 10448-71, 10559-66 (1960). Nevertheless, Secretary Udall failed to require observance of the excess land law in the contract he executed with the State of California on December 30, 1961. 108 Cong. Rec. 5717-21 (1962). See Taylor, Excess Land Law: Secretary's Decision? A Study in Administration of Federal-State Relations, 9 U.C.L.A.L. REv. 1 (1962).

31 See 1964 Westlands Hearing at 146-47. See also Taylor, The Excess Land Law: Execution of a Public Policy, 64 YALE L.J. 477, 501-06 (1955).

32 "During these early years the water project authority studied the subject and discussed it informally with officials of the Bureau. The necessity of change or elimination of this feature of the law as apphed to the Central Valley project was repeatedly brought to the attention of the Bureau. It was expected by the water project authority and others active in the furtherance of the project in California that, if it was finally determined that the excess-land provisions would be legally construed to apply under the terms of authorization of the project, that the excess-land provisions either would be removed by congressional action as in the case of similar projects such as the Colorado, Big Thompson project in Colorado and the Boca Dam project in Nevada, or by executive decision or action as in the case of the All-American Canal unit of the Boulder Dam project in California." 1944 Hearings on S. Res. 295, at 27.

33 Hearings on S. 912 Before Senate Public Lands Subcommittee, 80th Cong., 1st Sess. 27 (1947) [hereinafter cited as 1947 Hearings on S. 912]. 
find some way to subvert reclamation laws in . . the San Luis area."34 Democratic Senator Clair Engle, of California, offered an opinion that under a future Democratic Secretary "the law will be enforced," but Democratic Senator Paul Douglas, of Illinois, was skeptical that the problem was one of political party. "Sometimes Democratic Secretaries ... go sour, too," he said, adding: "If I may say so, I notice that the interests that are trying to operate against the welfare of the country have representatives inside botll parties and they operate inside both."138

Senator Douglas was specific as to his fears: The Southern Pacific, notably, might receive project water for its excess lands without agreeing to subdivide them as required by law. Whether he knew it or not, the Senator was echoing doubts expressed fifty-seven years earlier by Congressman George W. Ray, of New York. Unconvinced by assurances of western spokesmen pleading in 1902 for a national reclamation program, that the excess land laws would result in "breaking up any large land holdings" in the vicimity of reclamation projects, ${ }^{38}$ Ray led the opposition to all federal reclamation. "We find behind the scheme," he had said, "the great railroad interests of the West, who own millions of acres of ... arid lands . . . ." The value of these lands, he asserted, "will be multiplied by 10 " and even "by 20 " at the "very moment that we, at the public expense . . . construct these irrigation works . . ."

Spokesmen for the San Luis project regularly gave assurances that the law would be applied, as their predecessors had answered the skeptics of 1902. At the first presentation of the San Luis project to the Senate in 1958, Senator Wayne Morse, of Oregon, inquired whether the project would be economically feasible with Southern Pacific excess land holdings ineligible to participate. ${ }^{40}$ Senator Thomas H. Kuchel, of California, responded that "in my judgment, they will be compelled to participate through the force of public opmion." Senator Clinton P. Anderson, of New Mexico, added immediately that "in iny judgment, the Southern Pacific will reverse its decision . . . and will subdivide its lands." ${ }^{\prime 1}$

\footnotetext{
34105 Cong. REC. 7688 (1959).

35 Id. at 7495.

36 Ibid.

37 Ibid.

3835 CoNG. REc. 6678 (1902).

3035 Cong. REc. ApP. 256 (1920). In 1960 Congress authorized public investment of about $\$ 483$ million to reclaim the San Luis Federal Service Area which lad an assessed valuation of about $\$ 20$ million. On October 20, 1964, landowners approved Westlands construction contract by vote of $12,399,817$ to 388,328 , each vote representing $\$ 1$ of assessed valuation. Westlands District includes approximately four-fifths of the entire Federal Service Area. See Fresno Bee, September 16, 1964, p. 10-c, col. 1.

40 See 104 Cong. Rec. 17733 (1958). See also note 44 infra.

41104 CoNG. Rec. 17733 (1958).
} 
At the following Congress when the San Luis authorization bill was brought again before the Senate, Senator Kuchel renewed his assurances:

It should be made crystal clear that the federal acreage limitations will be enforced in the case of those benefiting from the Federal project in this joint venture .... [T] There is every intention on the part of the authors of the bill to have the Federal Reclamation law apply completely to every drop of water which goes into the San Luns Dam and which thereafter is to be used on properties lying within the expanded Federal reclamation area. ${ }^{42}$

As will appear, it is one thing for the legislative branch of government to decide to apply reclamation law to a project; but it turns out to be quite another for the executive branch actually to apply it.

\section{III}

\section{ENFORCEMENT: TWO MEANINGS}

Before long it became clear that there was disagreement as to the meaning of "enforcement" of reclamation law. On the one side, Senator Douglas and his colleagues apparently meant execution of recordable contracts by excess landholders agreeing to dispose of their excess lands. ${ }^{43}$ Senator Kuchel apparently meant something else. He denied that Senator Douglas was "correct," and said that excess landowners were perınitted by law to elect either to ask for water by executing recordable contracts, or to decline to ask. "When a Federal reclamation project is created . . . if I am . . . a large landowner, I do not have to take supplemental water if I do not wish to do so."44

42105 CoNg. Rec. 7484 (1959).

43 "I believe in making the Southern Pacific Railway Co. obey the law. It has stated pretty directly that it does not intend to obey the law. The big estates do not want to accept it." Ibid. "The Boston Ranch does not want to accept it. They want to have tens of thousands of acres held under one ownership and still secure the irrigation waters." Id. at 7667.

44105 Cong. Rec. 7491-92 (1959). The complexities of detail in reclamation law and its application, confused rather than clarified the debate, and in so doing helped pave the way toward circumvention of the law. Another important example is the confusion between "financial feasibility" and "economic feasibility," which was shared by both sides in the Senate debate. "Financial feasibility" has never been seriously in question at San Luis; excess landowners, including the Southern Pacific, are willing to meet financial obligations to the United States. "Economic feasibility," on the other hand, concerns a relationship between project costs and benefits to eligible lands adjudged to be either favorable or unfavorable to authorization of construction of the project. Expending full authorized San Luis costs of $\$ 483$ million to benefit only $30 \%$ of the San Luis lands, because $70 \%$ are legally ineligible to receive project benefits, raises per acre costs, and reduces "economic feasibility." Project costs are about $\$ 1,000$ an acre, provided all lands qualify as eligible to "receive water" ( $\$ 483$ million authorized to develop about 496,000 acres). If, however, eligible lands renain at only $30 \%$ because $70 \%$ are ineligible, costs per acre rise to $\$ 3,333$. 
Geology of the San Luis Service Area furnishes the clue to an explanation of how both sides in Senate debate could proclaim their devotion to reclamation law with apparently equal fervor, yet at the same time disagree so completely on the question whether law would be enforced or violated. A ground reservoir fed by underground sources and seepage from water applied to the surface underlies the Federal San Luis Service Area. Once in the ground reservoir, water is plysically available through pumping to both eligible and ineligible lands. Against this geological background, two contrary interpretations of "enforcement" have been advanced.

"The situation in question," said Senator Kuchel, "does not involve a violation of acreage limitation law. That ought to be made abundantly clear." ${ }^{\prime 45}$ Senator Morse insisted there was violation. Under the Westlands Water District contract with the United States, he said, application of the acreage limitation would be limited to "surface water" and would unlawfully ignore the "undue enrichment that the large landowners would receive from a raising of the underground water level." Owners of ineligible lands "would take the water out with . . . pumps" without regard for the excess land law. "That is the ginumick."

On another occasion Senator Kuchel clarified beyond any doubt his own meaning of obedience to the excess land law, and established agreement with Senators Morse and Douglas on the exact point of difference between himself and them. "Underground seepage of water delivered to their neighbors is not . . a 'delivery' within the neaning of the acreage limitation ...." he wrote. "The nuaterial fact is whether or not they receive project water by surface delivery and . . . until they ask for that privilege there is no way to force them to sign a recordable contract to dispose of excess land." ${ }^{\prime 7}$

This Article will establish that there is no legal justification for the view that deliveries of ground water at San Luis are exempt from the excess land law and that the law is currently being violated througl official nonenforcement.

This alters the measure of "economic feasibility" vastly. Usually "economic feasibility" affects legislative or administrative decisions whether or not to proceed with a project. During Senate debate the matter was thoroughly confused, and "economic feasibility" or infeasibility apparently carries hittle present weight with the Secretary of the Interior. In 1959 Senator Kuchel sought to reassure his opponents by quoting Senate Interior Committec Counsel Stewart French, in an ambiguous passage reading: "Refusal of Southern Pacific to [execute a recordable] ... agreement would in no way jeopardize the project." Senator Kuchel was clearly misled in adding to this statement the qualifying phrase, "from the standpoint of economic feasibility." See 105 Corc. REc. 7492 (1959).

45110 Cong. Rec. 17915 (daily ed. Aug. 7, 1964).

46 Id. at 17919.

47 Letter From Senator Thomas H. Kuchel to J. B. Neilands, May 13, 1964 (*). 


\section{IV}

\section{LEGAL FOUNDATIONS OF CIRCUMVENTION}

The language of reclamation law, already quoted, ${ }^{48}$ requires the Secretary of the Interior to prevent ineligible lands from receiving project water. The language of the statute makes no distinction between water received at the surface and water received underground. The legislative history of the reclamation law offers no evidence of congressional intent to distinguisl between surface and underground deliveries of water at San Luis or elsewhere on Central Valley Project. ${ }^{49}$ On the contrary, Congress has reserved to itself the power to make any such distinction, project by project. Citing congressional exemption of the Santa Maria, California, Project where "water utilized on project lands is acquired by pumping from the underground reservoir," the United States Supreme Court observed, "significantly, where a particular project has been exempted because of its peculiar circumstances, the Congress has always made such exemption by express enactment."50

Administrators of the San Luis unit, nevertheless, have taken it upon themselves, in applying the excess land law, to distinguisl between deliveries of water at the surface, and deliveries by seepage from the surface into the ground reservoir.

Commissioner of Reclamation Floyd E. Dominy has advised the Senate that although recordable contracts will be required to qualify excess lands to receive surface deliveries of water, these will not be required of those who, instead, "choose to continue pumping" from underground waters that will have been improved by "deep percolation losses froin surface water applications," including surface applications of project water. ${ }^{51}$ The Department of the Interior, represented before the Senate Interior Committee by Assistant Secretary Kenneth Holum and Solicitor Frank J. Barry, supported this position, which was embodied in the contracts to carry out the project between the Department of the Interior and Westlands Water District. ${ }^{52}$

\footnotetext{
48 See text accompanying note 21 supra.

49 No bill to make this distinction on Central Valley Project has been introduced. The most extensive argument on practical difficulties of enforcement under ground reservoir conditions was advanced by Senator Sheridan Downey, of Cahifornia, during efforts from 1944 to 1947 to persuade Congress to exempt Central Valley Project from the excess land law. These attempts failed. See 1947 Hearings on S. 12 ; 1944 Hearings on S. Res. 295; DowNEY, THEY WOULD RULE THE VALIEY (1947).

50 Ivanhoe Irr. Dist. v. McCracken, 357 U.S. 275, 292 (1958) (referring to exemption of ground water by 68 Stat. 1190 (1954)).

51 Letter From Commissioner of Reclamation Floyd E. Dominy to Senator Henry M. Jackson, Chairman, Senate Interior and Insular Affairs Committee, May 26, 1964, cited at 110 Cong. Rec. 17497 (daily ed. Aug. 5, 1964).

521964 Westlands Hearing at 15-44.
} 
The views of the Manager-Chief Counsel of Westlands Water District, Ralph M. Brody, were in accord with those of Commissioner Dominy and the Interior Department spokesmen before the Committee. He, too, recited the legal prohibition of water delivery to inehigible lands; ${ }^{63}$ he conceded that water "applied at the surface as a result of project activities" will seep into the underground $;^{54}$ he denied that execution of recordable contracts is required by law as precondition of construction or for receiving project seepage water; he insisted that neither temporary nor even permanent refusal of excess landowners to quahify their lands by executing recordable contracts, although receiving underground project waters, contravenes the excess land law..$^{55}$

Senator Thomas H. Kuchel, of California, as noted earlier, was exphicit in declaring the existence of a legal distinction between surface and underground water deliveries. ${ }^{56}$ He grounded his position, he said, "upon the advice of the Solicitor's Office of the Department of the Interior and after consultation with counsel on the staff of the Senate Interior Committee." $" 57$

The Westlands water service contract of June 5, 1963, provides specifically that project water pumped from underground is outside the scope of the excess land law "if such water reached the underground strata ... of excess land as an unavoidable result" of furnishing project water to eligible lands. Assistant Secretary Kenneth Holum justified this as "the standard Central Valley contractual clause."

This exclusion of "unavoidable" delivery of water into the ground reservoir from application of the excess land law, apparently first received official legal attention in the middle nineteen-forties. At that tiune Senator Sheridan Downey, of California, was leading a vigorous and persistent, but unsuccessful campaign to persuade Congress that the difficulties of applying the excess land law to water received by ineligible lands through the ground reservoir justified congressional exemption of Central Valley Project from the law. ${ }^{59}$ In 1947 the Chief Counsel of the Bureau of Reclamation, Chifford E. Fix, submitted a statement to the Senate Committee then holding hearings, reviewing the "legal basis for assessment. of excess landowners by irrigation districts." ${ }^{\text {" }}$ Chief Counsel Fix con-

53 Id. at 101, 114, 115.

54 Id. at 113. Assistant Secretary Holum estimated on July 9, 1964, that about $7.5 \%$ of surface water would seep into the ground reservoir. Id. at 25. On October 7, 1964, he estimated percolation at "between 10 and 15 percent." Id. at 179.

55 See id. at 101, 114.

56 See text accompanying note 47 supra.

57 Letter From Senator Thomas H. Kuchel to J. B. Neilands, May 13, 1964 (*).

681964 Westlands Hearing at 20-21.

59 See note 49 supra.

601947 Hearings on S. 912, at 1270-96. 
cluded, on the main point at issue, that the power of a district to assess landowners for benefits does not depend on delivery of water to their own lands. He quoted with apparent approval an earlier hypothetical statement by Commissioner of Reclamation Harry A. Bashore, namely, "if ... the physical introduction of project water on and under project lands has for its principal purpose, and its principal result is, the furnishing of irrigation water to eligible lands, with the incidental, and evitable [inevitable?] result that the underground water supply of inehgible excess lands is benefitted," that result is not to be construed as furnishing water contrary to the excess land law ${ }^{61}$ At the opening of his statement, Chief Counsel Fix had cautioned that "so far as underground waters are concerned," he was dealing with "potential" rather than actual "legal questions." 62 On this slender incidental consideration, the words of the "unavoidable" excuse clause, now in the Westlands contract, began to appear in Central Valley Project water district contracts.

Althougl the words are the same as those used in earlier Central Valley contracts, project conditions at San Luis are fundamentally different. The two conditions that Commissioner Bashore attached to his interpretation are unfulfilled at San Luis: (1) benefit to underground waters is not "incidental" but plauned as a major purpose of the San Luis Project;"63 and (2) the "principal purpose" and "principal result" are not furnishing water to eligible lands at San Luis but rather to the seventy percent of lands that are ineligible. The administrative precedent, therefore, is not applicable. ${ }^{64}$

The effort to discover a legal foundation for distinguishing between surface and underground water dehiveries on the San Luis unit resembles the midnight search in the cellar for the black cat that is not there. In mid-summer of 1964, Secretary of the Interior Stewart L. Udall and

61 Id. at 1274 .

62 Id. at 1270 .

63 See note 101 infra and accompanying text.

64 "This appears to be the genesis of the 'unavoidable clause.' No reference is made in the qnoted ruling to any applicable law permitting this evasion of the 'excess land law.' Congressional will cannot be relied upon in this matter because that will through the years has been unalterably opposed to the perpetuation of land and water monopolies. In simple terms executive fiat has been indulged in to create an exception to the excess land laws where none actually exists. Insidious though that evasion may be in the light of the law, the precedent stemming from the evasion is far worse. As is so frequently the case, a contempt for the law breeds further violation." Statement by Senator Gaylord Nelson on the Westlands Water District construction contract of 1963, 110 CoNG. REc. 17495 (daily ed. Aug. 5, 1964). The United States Supreme Court incidentally referred to the "unavoidable" clause in 1958, citing it as one item in evidence anong others (e.g., "subsidy" for reclamation) for concluding that the excess land law does not result in "damage constituting taking of property without compensation." Ivanhoe Irr. Dist. v. McCracken, 357 U.S. 275, 266, 295, 296. Cf. Testimony of Solicitor Frank J. Barry, 1964 Westlands Hearing at 37. 
Solicitor Frank J. Barry finally joined others in the search, virtually conceding its administrative futility by asking Congress to join also.

Responding to request by the Senate Interior Committee on August 1, 1962, for a study and report on the excess land law, the Secretary advised the Committee on June 30,1964, that "both Congress and the Executive Branch have on occasion exhibited a degree of concern for the excess-land owner which may be difficult to reconcile with the policies embraced by the excess land laws." ${ }^{, 65}$ The Secretary cited first among the "facets of excess land law or policy which merit further inquiry," that excess landowners have "not been required to comply with Federal excess land laws or to sign a recordable contract" when project waters "stabilize the underground, or reduce the rate at which it is being mined."

Thus the Secretary of the Interior apparently now makes no claim that the distinction between receiving water at the surface and receiving it underground is founded on law. ${ }^{67}$ Solicitor Barry explamed the Secretary's views to the Senate Interior Committee: "I want to point out to you that this letter was sent to the full committee for the purpose of alerting the Committee to the fact that ... . [indirect receipt of water by stabilization of the ground water table] is a problem and that consideration should be given to it." It seems that Solicitor Barry, the chief legal officer of the Department of the Interior, was unprepared four years after the passage of the San Luis Authorization Act, to state whether or not he supports a legal distinction between surface and ground waters. He told the Senate that he did "not want to give a legal opinion here"; that he "would prefer to study this matter with considerable care"; that he had "discussed this matter at considerable length with the people" on his staff, had "studied the matter myself," and could not "say at this point whether it is illegal ... to supply water under these conditions, or whether we can legally require . . a recordable contract." ${ }^{18}$

\section{$\mathrm{V}$}

\section{PARALYZED ADMINISTRATION}

Secretary Udall has advised Congress that the "executive branch," upon occasion, has "exhibited a degree of concern for the excess-land

65 Letter From Secretary Stewart L. Udall to Senator Henry M. Jackson, June 30, 1964, Acreage Limitation Policy, Study Prepared by the Department of the Interior Pursuant to a Resolution of the Senate Committee on Interior and Insular Affairs, Committce Print, xiii [hereinafter cited as Acreage Limitation Policy].

${ }^{66} I d$. at xi.

${ }^{67} \mathrm{Ibid}$.

681964 Westlands Hearing at 34. Solicitor Barry's uncertainty on July 8, 1964, contrasts sharply with Senator Kuchel's certainty on May 15, 1964, relying upon "advice of the Solicitor's Office," that the law distinguishes between surface and underground water dcliveries. See text accompanying note 57 supra. 
owner . . . difficult to reconcile" with the excess land law, and suggested that a part may have been played by "careful planming to take advantage of . . . exceptions to the acreage limitations."

Inability to devise adequate admimistrative procedures to enforce the law is not a sufficient explanation for its breakdown. As there is no legal basis for exempting ground water deliveries at San Luis, the simplest way for the Secretary to insure enforcement is to require excess landowners to execute recordable contracts before he spends public funds to construct the project. Indeed, under the ground reservoir conditions that characterize the Federal Service Area, the Secretary appears to have no practicable, effective alternative. Congress, by requiring one-liundred percent compliance by holders of excess lands as a condition precedent to construction of an earlier project has even provided the Secretary with legislative precedent for this procedure. ${ }^{70}$

The Secretary of the Interior, however, has been following an opposite course at San Luis. If continued, this can lead only to violation of the excess land law. The Secretary has allowed four years to pass smce Congress authorized the San Luis Project ${ }^{71}$ without requesting execution of any recordable contracts. ${ }^{72} \mathrm{He}$ has, however, asked Congress for authorization to spend 157 million dollars beyond the 290 million dollars authorized in 1960 for construction now under way to build water distribution and drainage systems within the Federal Service Area $^{73}$ for privately-owned lands, seventy percent of which are meligible to receive the project benefits-surface and ground water-he is preparing to confer. In addition, he has joined with others to ask Congress, and has obtained, an appropriation of 1.5 million dollars to begin construction. ${ }^{74}$

The Commissioner of Reclamation lias explained to Congress that it is not his intention to ask excess landholders for recordable contracts prior to construction. In support of this lie cited procedures adopted at other times and under other circumstances. He noted that earlier Central Valley Project contracts "establish no specific time prior to which large landowners must have placed their excess lands under recordable contract .... In the normal course the majority ... are executed shortly before irrigation facilities have reached a stage of completion where water deliveries can be made." ${ }^{.75}$ The Commissioner failed, however, to advise

\footnotetext{
69 Acreage Limitation Policy xiii.

7052 Stat. 211 (1938), 43 U.S.C. 600(a) (1958).

7174 Stat. 156 (1960).

72 One excess landowner has requested and executed a recordable contract making 480 acres eligible to receive water. Letter From Assistant Secretary of the Interior Kenneth Holum to Rev. James L. Vizzard, S.J., National Catholic Rural Life Conference, July 9, 1964 (*).

73110 Cong. Rec. 17495-96 (daily ed. Aug. 5, 1964).

74 Id. at 17912-22.

75 Id. at 17497. See also text accompanying notes 84-86 infra. The Commissioner's refer-
} 
Congress of the probability, if not certainty, that the procedure he proposed would frustrate the objectives of the excess land law.

First, even apart from the ground water problem, the Central Valley and other experience point to the legal inadequacy of the "normal course" of procedure, namely, to construct a project first and ask for recordable contracts later. In April 1964, twenty years after completion of Shasta Dam, the Bureau began to execute district contracts with Sacramento River diverters. Some unfavorable aspects of these longdelayed contracts are described below. ${ }^{76}$ No recordable contracts have been signed, and apparently few are expected, although large land holdings are prevalent along the Sacramento. ${ }^{77}$

In the spring of 1964, ten years after completion of Pine Flat and Isabella Dams, district contracts were executed. Whether recordable contracts will be obtained remains to be seen. Recordable contracts were obtained along the Friant-Kern and Madera canals with great difficulty in the late mineteen-forties and early nineteen-fifties, mainly through determination of administrators of the Department of the Interior at that time to enforce the law. On other reclamation projects-notably in Imperial Valley, California, constructed a quarter-century ago, and in the Salt River Valley, Arizona, constructed a half-century ago-no recordable contracts have been requested or offered. ${ }^{8}$ Enforcement of the excess land law is entirely absent.

Second, on the San Luis Federal Service Area, geological conditions prevent administrative control of water distribution as between eligible

ence to Central Valley Project precedent was misleading. Central Valley procedure itself was not "normal" for reclamation projects, but exceptional. As the Chief Counsel of the Bureau of Reclamation had explained in 1947, the "conventional policy requirement" of even district contract execution-let alone contracts with individual landowners-"prior to the commencement of construction" was "waived" on Central Valley Project, specifically because the "public works program" to reduce unemployment, which supphied funds to begin the project, "required that money be expended with greater speed" than insistence on prior contracts "would have permitted." 1947 Hearings on S. 912, at 1271.

76 See text accoinpanying notes 137-50 infra.

77 See 110 Cowg. REc. 17501 (daily ed. Aug. 5, 1964).

78 Testimony of Northcutt Ely, Hearings on H.R. 3961 Before Senate Commerce Subcommittee, 78th Cong., 2d Sess. 632 (1944). See also testimony of Taylor, 1964 Westlands Hearing at 144. On February 24, 1933, under a ruling by Secretary of the Interior Ray Lyman Wilbur, application of the excess land law to Imperial Irrigation District was waived. Solicitor Fowler Harper criticised this in 1945. (M.33902, May 31, 1945, 16, 17). The Department of Justice, apparently, also disagreed in 1957 pleadings before the United States Supreme Court. (Arizona v. California) On May 7, 1964, 31 years after the waiver by Wilbur, an Acting Commissioner of Reclamation, referring to the original ruling and its criticism by the Justice Department, wrote that "the continuing press of other matters had caused us to defer a current study of the Imperial situation. We hope, however, to review this matter in the future as the circunstances of time permit." Letter From G. G. Stamm to Rowland Watts (*). 
and ineligible lands. Water applied at the surface on eligible lands in the Federal Service Area seeps into the ground reservoir from which it becomes available for use on ineligible lands by pumping from wells already installed. "Nonnal" procedure of executing contracts "shortly before irrigation facilities have reaclied a stage of completion where water deliveries can be made," therefore, is entirely unsuited to obtaining compliance with law. ${ }^{79}$ Delay in obtaining compliance with the excess land law reduces bargaining power of the Bureau of Reclamation almost to the vanishing point.

In the absence of firm legal justification for distinguishing between project waters received at the surface and those received underground, the present administrative paralysis at San Luis becomes intelligible only in terms other than law. When pressures from excess landholding interests find response ainong administrators of the excess land law, no recordable contracts are asked and the result is frustration of the law. ${ }^{80}$

Ground water conditions on the Federal Service Area liave been recognized by some Bureau of Reclamation officials for a quarter of a century as conducive to circumvention of the excess land law. Similar recognition by excess landholders invites serious efforts toward such circumvention. At least, spokesmen for excess landholding interests have long testified to their lope and expectations, and to a willmgness of some administrators to share them.

As early as 1937, according to a Kern County spokesman,

We were assured by officials of the Bureau of Reclamation that, as there were no public lands in the area and that at least half of the project water would be used, of necessity, for recharging the groundwater table and as there was no legal or physical way in which any land owner could be prevented from pumping wliat waters underlay his surface lands, that we could count with certainty that before the project was completed, the acreage limitations would be removed. Until 1944 this was the general understanding. ${ }^{81}$

In 1944 a large landowner, now Chairman of the Board of Directors of the Westlands Water District, advised Congress that a high engineering official of the Bureau of Reclamation liad indicated, in accepting 25,000 dollars from private large landholding interests to share costs of water surveys in the area, "that the 160-acre limitation was not to be taken seriously. It was their [reclamation officials'] suggestion."

79 Testimony of Taylor, 1964 Westlands Hearing at 132, 142-44, 146-47.

80 Cf. Taylor, supra note 31, at 501-06. See also 1964 Westlands Hearing at 146-47.

81 Testimony of Roland Curran, 1944 Hearings on S. 912, at 1310.

82 Testimony of Russell Griffin, Hearing Before Senate Military Affairs Subcommittee on Central Valley Water Project 93 (Mimeo. by Bureau of Reclamation, Sacramento, April 7, 1944). 
A month later a national magazime noted, in a discussion of tactics planned by "the big landowners in the valley . . . . to accomplish their end," that "landowners are sinking wells around their holdings in order to be prepared to pump irrigation water from the raised water table."

Again, im July of the same year, a spokesinan for Tulare Lake Basin Water Storage District, adjacent to Westlands District, testified that "no means either legal or physical have been suggested for preventing the continuation of such pumping. . . . The Bureau of Reclamation and others ... have admitted that the excess land provisions will not be effective in such ground water areas." applicable" and "practically effective" was carefully avoided.

Success of this tactic for circumvention of the excess land law is dependent, of course, upon a particular sequence of administrative actions. Specifically, success depends upon obtaining administrative delivery of surface water that will seep into the ground reservoir prior to administrative insistence upon execution of recordable contracts. By not insisting on execution as a precondition to construction, it will be far more difficult to obtain enforcement if it is later decided to apply the law to underground "deliveries." Perhaps it is hoped that the practical difficulties then encountered will marshal a legal interpretation of the statute favorable to the excess landholders, much as Senator Sheridan Downey in the nineteen-forties had hoped that such difficulties could be marshaled to produce legislative exemption.

In sum, the so-called "normal" procedure, accepted as appropriate by the Bureau of Reclamation, and followed since the San Luis Act passed in 1960, leads to circumvention of the excess land law on the Federal Service Area, as foreseen and planned. The Coinmissioner of Reclamation, apparently undetered by either prospective illegality or financial irresponsibility $\mathrm{m}$ his course of inaction, is content to delay asking for recordable contracts until "irrigation facilites have reached a stage of completion where water deliveries can be made." to risk heavy public investment for construction of canals that may never be placed in service legally, but once constructed are likely to be used illegally. ${ }^{86}$

83 Valley Divided, 767 Business WeEx 24 (May 13, 1944).

84 Testimony of S. T. Harding, 1944 Hearings on S. Res. 295, at 358.

85 See text accompanying notes $71-75$ supra.

86 The risk is increased by granting the District a veto over federal construction of water distribution and drainage systems to serve the district, in which $70 \%$ of the lands are inehgible to receive water and voting is by assessed valuation. The potential effectiveness of the veto in producing either wasteful construction or law violation, or both, is enhanced by the prevalence of "checker-board" landownership by the Southern Pacific, arising from original land grants to railroads. 
There appears to be no adequate legal justification for distinguishing between surface deliveries and purposeful ground deliveries. It appears equally certain, given the geological conditions at San Luis, that there can be only one effective means of enforcing the excess land law. Without substantiating their position on the law applicable to these geological conditions, proponents of the Westlands contracts have offered complex rationalizations in support of the current course of administration. The remainder of the present Article examines the defenses, rationalizations, and methods by whicls the law is being circumvented on the Federal San Luis Service Area.

\section{VI}

\section{GEOLOGY: AID TO CIRCUMVENTION}

The geological conditions of the San Luis Service Area have been offered by both the Commissioner of Reclamation and the Westlands Water District as support for the argument that economic pressures will compel excess landowners to execute recordable contracts in order to receive surface water. The administrators apparently believe that it is unnecessary to substantiate their position on the distinction between ground and surface deliveries since the economic pressures to receive surface deliveries will result in compliance with the law. Through this reasoning they seek to justify their unwillinguess to insist upon execution of recordable contracts prior to construction. ${ }^{87}$ In hight of this argument, a brief review of the geological factors in the San Luis Federal Service Area is appropriate.

The ground reservoir underlies the entire San Luis Service Area. ${ }^{88}$ Recoguizmg that this condition distinguishes San Luis from previous units of the Central Valley Project in the San Joaquin Valley, the San Luis project emphasizes replemshment of ground water as a major aim. The District water service contract recites that "ground water underlying the District is seriously depleted and in need of replemishment," and that "an additional water supply to meet these present and potential needs can be made available by and througli the works constructed and to be constructed by the United States." It allots an additional amount of water up to 117,000 acre-feet annually in order to replenish ground waters, should estimates of seepage from water delivered at the surface and reduction of overdraft from surface dehiveries prove low. ${ }^{89}$ The Bureau of

\footnotetext{
87 See text accompanying notes 94-97 infra.

88 Bureau of Reclamation, Sacramento, Geology and Ground-Water Resources, San Luis Service Area, Central Valley Project 17 (Feb. 1963).

89 Contract Between the Umited States and Westlands Water District Providing for Water Service 2, 8 (June 5, 1963) (*).
} 
Reclamation plans to provide facilities "for integrating ground water with surface water," to integrate about " 400 existing deep wells . . . into the distribution system," and to mix "well water" with "surface project water in the main laterals."

The Commissioner of Reclamation explains that the water supply of the area will be derived from three sources: (1) pumped water from the deep zone (the water table will be raised from a present level of about 450 feet to about 300 feet, by a combination of reduced pumping drafts on "nondistrict natural recharge," and seepage from surface deliveries); (2) "project surface water"; and (3) "groundwater supply resulting from deep percolation losses from surface water applications. ${ }^{291}$

Studies by the Geological Survey corroborate the presence of ground water reservoir conditions favorable to the success of San Luis project as planned. Water seeps downward and laterally. Its direction of flow underground can be influenced by pumping. A layer of less permeable Corcoran clay divides the San Luis reservoir into an upper and lower zone. This has been cited to support argument that little, if any, surface water will reach the pumps that draw upon waters in the lower zone. ${ }^{92}$ However, the Geological Survey indicates that the deep zone is rechargeable from surface applications of water, whether by lateral movements or by percolation assisted by punctures through the clay made by 1,000 active, and by 2,000 abandoned wells. ${ }^{.3}$

The Commissioner of Reclamation, who has used his knowledge of these geological conditions to plan a project to integrate fully the supply of surface waters with the replemishing of ground waters, clains: (1) that surface water applications will seep underground; (2) that applications of surface water combined with seepage will raise the water table, bringing waters that have been moving steadily out of economical reach of pumps; and (3) that he does not intend to deny project water to ineligible lands provided it reaches them via the ground reservoir. ${ }^{94}$ The Commissioner does not intend to insist, prior to construction of the project, upon

80 Memorandum From Commissioner of Reclamation Floyd E. Dominy to the Secretary of the Interior, April 23, 1964, cited at 110 Cong. Rec. 17496 (daily ed. Aug. 5, 1964).

01 See Letter From Commissioner of Reclamation Floyd E. Dominy to Senator Henry M. Jackson, May 26, 1964, cited at 110 Cong. Rec. 17497 (daily ed. Aug. 5, 1964).

92 Letter From Ralph M. Brody, Manager-Chief Counsel, Westlands Water District, to Senator Frank E. Moss, Chairman, Senate Subcommittee on Irrigation and Reclamation, June 11, 1964 (*). See Testimony of Ralph M. Brody, Westlands Hearing at 113.

93 United States Dept. Interior, California Department of Water Resources, Geological Survey Water Supply Paper 1618, "Use of Ground-water Reservoirs for Storage of surface water in the San Joaquin Valley, California" 24, 41-45, 81-88, 117-19 (1964).

94 See Letter From Commissioner of Reclamation Floyd E. Dominy to Senator Fenry M. Jackson, Chairman, Senate Interior and Insular Afiairs Committee, May 26, 1964, cited at 110 Cong. Rec. 17497 (daily ed. Aug. 5, 1964). 
execution of recordable contracts necessary to qualify the seventy percent of presently ineligible lands to receive the ground water benefits the project will confer upon them. He offers, as a substitute, an expectation that economic pressures to obtain surface deliveries will result in execution of recordable contracts. These pressures, it is argued, will arise from the cost differential favoring surface over pumped water, and from ad valorem taxes levied on all lands within the district whether they receive surface water or not. ${ }^{95}$ The Commissioner of Reclamation states in support of his view, and the Manager-Chief Counsel of Westlands Water District agrees, that the District will apparently raise funds for repayment to the United States by using a combination of toll cliarges for water delivered by surface to eligible lands, and ad valorem assessments on all district lands to cover the imsufficiency of funds collected from tolls. ${ }^{96}$ This manner of raising funds obliges owners of eligible lands to pay twice, and owners of ineligible lands but once. An opportunity to obtain cheaper water is undoubtedly an incentive to execute recordable contracts, but the proposed measures to raise district funds appear more likely to operate in an opposite direction. It is improbable that a district controlled by excess landholders owning seventy percent of the lands and voting by assessed valuation, would manipulate the means and measure of sliared repayment to their own disadvantage.

An element of uncertainty in the effectiveness of the pressures is conceded by acknowledgment that "it is impossible" to "predict at this time the extent and sequence that may characterize the rate at which" the Southern Pacific (and presumably other excess landholders) "will embrace the recordable contracting program."197

In substance, the Commissioner confesses that project water will reach ineligible lands via the ground reservoir, as Senator Sheridan Downey pointed out long ago. ${ }^{98}$ This is precisely what reclamation law would seem

85 See also testimony of Ralph M. Brody, 1964 Westlands Hearing at 113-15.

96110 CoNG. Rec. 17497 (daily ed. Aug. 5, 1964); Testimony of Ralph M. Brody, 1964 Westlands Hearing at 102; Testimony of Assistant Commissioner of Reclamation G. G. Stamm, id. at 30-32.

07 See note 91 supra. See also note 111 infra.

98 Senator Sheridan Downey of Cahifornia argued in 1947 that "there is no way of preventing the excess-land owner from getting ground-water benefits once . . placed in a common ground table." Downey, Thex Would RULe the Valley 102 (1947). Although owners of excess lands on the Orland Project, operating successfully in the Central Valley since about 1909, had voluntarily accepted a forty-acre limitation, Senator Downey dismissed as "naive" a "hope" expressed by Assistant Commissioner of Reclamation William E. Warne that on the Central Valley Project "excess landowners voluntarily would give a recordable option to the Secretary simply to promote the general commumity interest." 1947 Hearings on S. 912, at 1216-17. The Senator also rejected as "illogical and inconsistent" the assertion by Bureau officials, conformable to law, "that if the hinitation cannot be applied ... water should be denied ..... Id. at 1200. Apparently fearful that the excess land law 
expressly to forbid..$^{99}$ It remains to assess the total argument that no violation of law is occurring at San Luis.

\section{VII}

\section{IEGISLATIVE POLICY ABANDONED: A BRIEF SUMMARY}

Those who contend there is no violation of the excess land law at San Luis have made the two principal arguments already examined. The first is that the excess land law in no case applies to water received through the ground reservoir. This has already been shown to be legally tenuous. Even conceding, arguendo, that "unavoidable" ground deliveries might be judicially exempted from the statute, this seems totally inappropriate in the San Luis project ${ }^{100}$ where ground water will be replenished by design, ${ }^{101}$ thereby bringing project water to already installed pumps. The second is that whether or not the law applies to underground deliveries, economic pressures eventually will compel execution of recordable contracts by excess landowners desirous of receiving surface water. Assuming, again arguendo, that such pressures are a proper substitute for strict legal enforcement, we have seen ${ }^{102}$ that there is small probability that these pressures will operate to compel execution of recordable contracts by excess landowners receiving substantial groundwater benefits.

Two further arguments have been made: (1) timing of requests for execution of recordable contracts is wholly within official discretion; and (2) execution of recordable contracts is entirely a matter of choice by excess landowners, a choice to be exercised after construction is underway.

As to the first, there is noteworthy agreement between officials of the Interior Department and officials of the Westlands Water District in respect to their unwillingness to require execution of contracts as a condition precedent to construction. There can be little doubt that a prompt demand for contracts would remove the possibility that the Secretary will allow violations of the excess land law. The question of timing of the request for these contracts has, however, produced a remarkable array of explanations for the Secretary's reluctance to make such demand.

might be enforced administratively by denial of water to ineligible lands, the Senator worked indefatigably for congressional exemption.

98 See text accompanying notes 48-68 supra.

100 See Statement by Senator Gaylord Nelson quoted at note 64 supra.

101 "Ground water underlying the district is seriously depleted and in need of replenishment, and ... an additional water supply to meet these present and potential needs can be made available by and through the works constructed and to be constructed by the United States." Westland Water Service Contract, June 5, $1963\left(^{(*)}\right.$.

102 See text accompanying notes $87-99$ supra. 
Solicitor of the Interior Frank J. Barry advised the Senate:

Suppose that . . . someone on the Westlands District . . . feels that he wants to see whether his ground water will be sufficiently improved by the project so that he can derive water from the underground rather than sign a recordable contract. Now, he has unlimited time.103

Senator Gaylord Nelson, of Wisconsin, asked the Interior Department spokesman: "Why . . . not insist that the contracts all be signed before we launch into a $\$ 150$ milhon project?" In reply, Assistant Commissioner of Reclamation G. G. Stamm said, "The law does not require it," but acknowledged that the law "does not prohibit it."104

Solicitor Barry conceded that the Secretary could simply say "I ain not going to build a project until I am satisfied." He also volunteered that "if Congress wants to prescribe" that the Secretary is not to "build a project until [he has] everybody signed up," he, the Solicitor, "probably would cheer, personally." However, he would "advise the Secretary . . . that this is not a legally valid ground to object to this contract, notwithstanding . . . that there are people who liold another view."105

The Solicitor discussed the Secretary's powers of administrative discretion in respect to execution of recordable contracts, but failed to advise the Senate that Congress itself, upon at least one occasion in 1938, liad required "that construction work is not to be mitiated ... until ... contracts shall have been made with each owner of more than one hundred and sixty irrigable acres ... by which lie ... shall be obligated to sell all of his land in excess . . ." 106 In the same Senate hearing, while Senator Kuchel was presiding, this Congressional Inandate was quoted. The witness pointed out that this congressional inandate buttresses the exercise of discretionary power of the Secretary to insist on prior execution of contracts when necessary, as at San Luis, to prevent violation of law. ${ }^{107}$ Notwithstanding this quotation of the statute and a colloquy on the sub-

103 Referring to Central Valley experience, Solicitor Barry added that an excess landowner "may wait ten, fifteen or more years before le calls for project water. The delay is deliberately availed of by landowners to determine by actual experience whether they will liave sufficient benefits from the stabilization of the ground water to stave off the need for ever calling for direct delivery of water and thereby subjecting their lands to reclamation law." 1964 Westlands Hearing at 34.

104 Id. at 32 .

$105 I d$. at 36 .

10852 Stat. 211 (1938), 43 U.S.C. § 600(a) (1958). [Emplasis added.] The original transcript of 1964 Westlands hearing records this response by Solicitor Frank J. Barry to a question from Senator Kuchel: "So far as I know, this has never been [the last three words are stricken by pen]-no one las ever required that recordable contracts be secured before the project is constructed." (p. 56). The entire quotation from the transcript is omitted from the printed hearing. (p. 35). See also statute cited note 70 supra.

107 Testimony of Taylor, 1964 Westlands Hearing at 137-38. 
ject between witness and presiding Senator on July 8, 1964, Senator Kuchel, while pleading with the Senate to approve an appropriation to begin construction at Westlands on August 7, 1964, said Congress had never passed such a law. ${ }^{108}$

As to the second argument, the Manager-Chief Counsel of Westlands District, in harmony with the view of Solicitor Barry and Senator Kuchel, emphasized that execution of contracts prior to construction is "not a statutory requirement," that an excess landowner is not required to execute a contract "if he does not desire . . . water," and that "the law contemplates a choice upon his part."109

At the July 8, 1964 hearing before the Senate Interior and Insular Affairs Committee, when the Westlands contract was under attack, Manager-Chief Counsel Brody stated that "Mr. Russell Giffen, the Chairman of our Board of Directors . . . said . . . he intended to sign a recordable contract, that he was morally obligated to do so . . . ." He added that Producers Cotton Oil Company "was of the mind to sign . . . and intended to, and I know there has been no change in attitude . ..." He said also that "Mr. Diener, another Board member, as far as I am aware, intends to sign a recordable contract," and that "I have had discussions with a considerable number of landowners who see that they have no alternative."110 Mr. Brody qualified his imformation with a vague statement, that "I cannot conceive of any landowner, no matter what his imtentions ... a actually signing [a recordable contract] until the [ground?] water became available, or until he wanted water for his land." Then he held up the spectre of a lone hold-out, or even "any portion of the landowners," whose refusal to sign nnglt "defeat the very purpose for which the project is being built, and that is to serve those people who are ehgible." $" 111$

108 "Congress has never required ... that the landholders in every block of property within that district sign such a contract ... . If we wish to ask Congress to make every single landowner, as a condition precedent, sign a contract, let a bill be introduced ..... But, do not single out one irrigation project in iny State, and do not say that we are not going to approve the item for this project ...."110 Cong. REc. 17918 (daily ed. Aug. 7, 1964).

109 Testimony of Ralph M. Brody, 1964 Westlands Hearing at 114. He added that "Congress wisely concluded that through the taxing power of the districts . . . [excess landowners] would be forced through economic circumstances to execute a recordable contract." No evidence for this view was cited, and there appears to be none.

$110 \mathrm{Id}$. at $109-10$.

111 Id. at 110. A greater fear was possible administrative creation of "situation and circumstances" (by demanding execution of recordable contracts, or in lieu thereof, the designation of the particular 160 acres chosen from among total landholdings to receive project water) that would lead to quick decision. This administrative action would tap the same economic necessity of landholders for water that they relied upon originally to persuade Congress to authorize spending $\$ 483$ million for thcir benefit, conditioned by the excess land law. Objecting to this administrative procedure, Mr. Brody testified: "They 
The apparent contradictions between intending to sign later, and unwillingness to sign now in order to assure the start of construction, and between earlier distressed pleadings for authorization by Congress to prevent return of lands to sagebrusl, and later insistence upon a "right to choose between compliance or non-compliance at one's pleasure," were not explained. Neither was it clear how much weight the Senate Committee should attach to a sense of inoral obligation felt by an official of Westlands District owning excess lands, nor how widely the feeling was shared by other excess landholders in the district. Mr. Brody did not say in 1964 whether, in his opinion, Southern Pacific would be among those landowners whose unwillingness to sign might stand in the way of serving "those people who are eligible." Five years earlier, however, while authorization of San Luis project was pending, Senator Clinton P. Anderson, of New Mexico, had expressed an opinion that the conipany would "subdivide" its lands under the excess land law, for "no corporation in its riglit mind would take that land out of cultivation . . . ."112

Reviewning the opinions expressed it appears that Senator Sheridan Downey's early description of escape froin the excess land law by getting ground waters first and then deciding afterwards whether to sign recordable contracts fits San Luis today. As Solicitor Barry stated on July 8, 1964 , "delay is sometimes deliberately availed of to stave off the need ..." to comply with the law in order to obtain surface water. This means of circumvention assumes, as previously noted, that Congress is willing to authorize the project and appropriate funds, and that the Secretary of the Interior is willing to proceed with construction without knowing which lands are eligible to benefit under the law, or at San Luis, knowing that seventy percent of the lands are ineligible. Both assumptions appear to be realized; Secretary, Congress and large landholders join in shunning the inquiry that would determine officially and quickly the willingness of excess landowners to render their lands eligible. Federal reclamation law and its avowed purposes are not being debated, repealed and disavowed. They are nerely being abandoned.

\section{VIII}

\section{STATUTORY PROCEDURES IGNORED}

The contracts between the United States and the Westlands District deviate froin certain procedural requirements of the San Luis Act. The

want this thing to happen overnight. These holdings were not built up overnight. It took a long time and it will take a long time ... to be broken up. . . Y You cannot physically force a man to put his name to a contract. All you can do is to create a situation and circumstances under which he is going to find it impossible for him to continue economically ... to operate as he has in the past." Id. at 102.

112104 Cong. Rec. 17733 (1958). 
effect of these deviations may facilitate the circumvention of the excess land law on the Federal Service Area.

Because of ground water conditions, the natural and immment prospect of water deliveries to the Westlands District will improve the ground reservoir and raise the water table throughout the entire Federal Service Area, of which it is a part. Westlands does not include about 105,000 acres of the Federal Service Area which lie largely if not entirely within the West Plains District.

The San Luis Act specifies that the Secretary of the Interior shall transmit to Congress "a contract" for construction of water distribution and drainage systems within the covered area. No provision is made for two contracts within the same Federal Service Area. ${ }^{113}$ Nevertheless, Assistant Commissioner of Reclamation G. G. Stamm told the Senate Interior Committee that the Bureau expects to "have contracts with both the Westplains . . . and the Westlands Water District." These two areas together, he said, include "all of the [San Luis] Federal Service Area . . . essentially in one irrigation district." 114

The effect of this deviation is not trivial. The 105,000 acres of the Federal Service Area lie mostly or all within the Westplains District witl which a contract for construction of distribution and drainage systems has yet to be executed. Irrespective of the expressed intentions of the Bureau, Westplains is currently without legal provision for construction of project facilities. Meanwhile, Westlands District has preempted 157 million dollars of the 192 million dollars authorized by Congress in 1960 to serve the entire Federal Service Area. The balance of 35 million dollars may not be sufficient to complete the San Luis project. The San Luis Act assigns no priority to Westlands District, but the effect of administrative action is to give it priority.

Notwitlustanding this priority of construction, benefits to the Westplains area will accrue from improved ground water. The failure of the Bureau of Reclamation to follow prescribed procedure leaves this area without legal arrangements for construction and without methods for obtaining compliance with the excess land laws. This facilitation of circumvention is all the more startling when one considers that a single landowner, the Southern Pacific, owns about 55,000 acres, or over half of the total acres in the excluded area.

Deviation from the procedures prescribed by Congress goes even farther. The San Luis Act requires that Congress approve fully executed

\footnotetext{
11374 Stat. 156 (1960). But see testimony of Brody, 1964 Westlands Hearing at 109. "There has never been a requirement that there be one district or one contract to cover an entire project service area."

1141964 Westlands Hearing at 22.
} 
contracts with the water districts before the project is begun. ${ }^{115}$ In transmitting legal arrangements with Westlands District to Congress, the Department of Interior submitted not one fully executed contract, but two "contracts": (1) a water service contract, fully executed, but submitted to Congress only by reference; and (2) a "form" or "proposed" contract-but not an executed contract-for construction of distribution and drainage systems. Nevertheless, Secretary of Interior Stewart I. Udall described the construction contract document as "a contract" in transmitting it to Congress. ${ }^{116}$ Secretary Kenneth Holum called it a "contract" and a "form"; "117 Commissioner of Reclamation Floyd E. Dominy called it a "form" or "proposed" contract, but also referred to it as "a contract." Congress did not discuss this departure from legally prescribed procedure publicly during the ninety-day period during which the Westlands documents lay before it in the summer of 1964, and may not even have observed it.

The seriousness of this failure to follow statutory procedure may appear shortly. On October 9, 1964, Assistant Secretary Holum advised Senator Henry M. Jackson, Chairman of the Senate Interior Committee that Secretary Udall had "determined that certain modifications should be made in the water service contract" executed with Westlands District on June 5,1963 , that lay before Congress for the prescribed ninety days in 1964. He expressed no intention to resubmit it to Congress after administrative revision. ${ }^{110}$ On October 20,1964, Westlands Water District voted on, and approved, the original "proposed" or "form" construction contract that lay before Congress for ninety days. ${ }^{120}$

The hand of Congress will be removed from enforcement of the excess land law on the Federal San Luis Service Area unless the contractual arrangements actually covering that area are placed properly before it. Until now they have not been, due to a failure to adhere to legally prescribed procedure.

11574 Stat. 156 (1960).

110 Letter From Secretary Udall to President pro-tem. of the Senate Carl Hayden, April 24, 1964, 1964 Westlands Hearing at 3.

1171964 Westlands Hearing at 15, 17.

118 Id. at 3,5 .

119 On the contrary, he hoped that by amending the water service contract only, and not the "form" or "proposed" construction "contract," he might avoid resubmittal, notwithstanding alterations from the text originally before Congress for the required ninety-day review. Letter From Assistant Secretary Kenneth Holum to Senator Henry M. Jackson, Chairman, Senate Interior Committee, October 9, 1964, at 177; Memorandum, Holum to Udall, October 7, 1964, at 17\%-80.

120 "Westlands Farmers Okeh Water Pact," Fresno Bee, October 21, 1964, p. 1, col. 3. Landowners voted 475 to 25 in favor of the contract (by assessed valuation, $\$ 1$ per vote, the result was $12,399,817$ to 388,328 ). Authorized federal investment in San tuis unit is $\$ 483$ million. 


\section{IX}

\section{IEGISLATIVE OVERSIGHT: CIRCUMVENTION COMPLETED}

The requirement that a contract for construction of water distribution and drainage systems shall lie before Congress for ninety days before it can be made effective is known as "legislative oversight." At San Luis, legislative oversight has proved to be double-edged. The excess land law and the prospect it holds there for creation of few thousand family-size farms operated by their owners-the original promise of federal reclamation -are the victims. The damage is worse than executive violation of law. Through legislative oversight the violation subtly gains the formal appearance of congressional concurrence.

Two Westlands contracts, transmitted by Secretary Udall on April 23, 1964, lay before the Senate and House for ninety days as prescribed by law. ${ }^{321}$ The House Interior Committee approved them almost immediately, without hearing. However, no item to begin construction of Westlands water distribution and drainage systems appeared in the public works appropriation bill passed soon thereafter by the House. The Senate Interior Committee, after two months had elapsed, held a one-day hearing on Westlands contracts on July 8 , but the Committee itself remained silent. A few days before expiration of the required ninety days of legislative oversight the Senate Appropriations Committee, without hearing, proposed a 1.5 million dollar token item to begin construction at Westlands, and the Senate passed it. A vigorous attempt by opponents of Westlands contracts to strike the item from the bill was defeated, fiftyseven to twenty-three. ${ }^{122}$

Presumably, the purpose of ninety-day "legislative oversight" is to give Congress opportunity to verify, in advance of execution, that proposed administrative measures shall conforn to law and will achieve the purposes of law. On the San Luis unit of the Central Valley Project, Congressional inaction during the running of the ninety-day period has apparently resulted in precisely the opposite-circumvention and violation-not in fulfillment of law. ${ }^{123}$ Such circumvention and violation de-

121 The San Luis Authorization Act of June 3, 1960, 74 Stat. 160 (1960), specifies submission of "a contract" to Congress for legislative oversight. Without explanation the Secretary of the Interior submitted two Westlands "contracts." A construction and repayment "contract" was submitted on May 1, 1964. A second contract, executed on June 5, 1963 to cover water distribution service, was submitted by reference only. The latter contains many of the provisions most destructive to effective enforcement of the excess land law. See 110 Cove. Rec. 17495-97 (daily ed. Aug. 5, 1964). See also text accompanying notes 115-18 supro.

122110 Conc. REc. 17922 (daily ed. Aug. 7, 1964). The House agreed to the item in conference, and it was included in the bill as passed by Congress.

123 Cf. Taylor, supra note 30; 108 CoNG. Rec. 5708-09 (1962). 
pends upon a willingness within the executive branch of government to allow circumvention and upon a similar willingness-or simply lack of knowledge - of those members of the Congress astride the channels through which legislative action is exercised. The process of circumvention within the Federal San Luis Service Area can be clearly charted.

First, the Congress originally decides what the law shall be through customary legislative procedures. It decided in 1960, after assurances that excess land law would be applied, that it would authorize and finance construction of the San Luis project.

Second, executive administrators of reclamation, in conjunction with the Westlands District, prepare two contracts that simulaneously recite the law as written and confess non-enforcement, offering as an excuse for making ground water available to inehgible lands, the "unavoidable clause." These are submitted to Congress.

Third, the contracts, referred to committees, lie before Congress under a time himitation of ninety days. Failure to act allows the Secretary of the Interior to proceed under the contracts. In this posture the excess land law is not faced directly but tangentially and incidentally to other matters: interior committees are concerned with promoting construction of projects and appropriations committees with financing them. Law and policy are not prime considerations under this kind of legislative oversight.

Originally, the full Congress held the whip hand over the San Luis project. Ability to insist upon the excess land law lay in the power to withhold authorization and finance from the project. This power was used on the San Luis bill. Under legislative oversight the whip is gone; the balance of political power is shifted. With authorization and finance in hand, incentive to act politically without regard to law is unchecked. Public principle and policy stand exposed to special interest and stark political pressure. ${ }^{124}$

A facade of official and party unanimity was thrown by Senator Kuclel over his appeal, on August 7, 1964, for an appropriation to begin construction at Westlands. He spoke, he said, "on behalf of" his Democratic colleague, Senator Pierre Salinger, "of the government of the State of California, of the Department of the Interior, of the Budget Bureau, of the administration of the late President Kennedy, and of the mcumbent Johnson administration."125 The appeal succeeded; the appropriation to

124 In a similar situation, also under the San Luis Act of 1960, legal counsellors advised the State of California that "The reaction of Congress and its relevant committees is more a political than a legal problem." Chas. T. Main, Inc., Final Report, General Evahsation of the Proposed Program for Financing and Constructing the State Water Resources Development System of the State of California Department of Water Resources 222-1-2A, app. 29 (1960).

125 The facade is contrived; it does not represent united popular support. In 1964 the 
begin construction was passed, and the Westlands contracts survived. The original statute remains but goes unenforced, its ends unachieved. Only a change of executive intent, or perhaps a difficult citizens' appeal to the courts appear as possible ways to alter this outcome.

"The hife of the law is in its enforcement."126 In these proceedings of the San Luis project, of which recent legislative appropriation to begin construction mark the culmination, "the law" has not been changed. Rather, as Roscoe Pound said long ago, "the limits of effective legal action" have been exceeded. ${ }^{127}$ Law has failed at San Luis, not in legislative deliberations on policy, not before the bencll, ${ }^{128}$ but at the bar of politics. This is because of a peculiarly effective combination of factors within the federal government operating in larmony with the purposes of a state-created water district-a district dominated by excess landholders whose financial interest in circumventing the excess land law is obvious. ${ }^{129}$

Interior Department and Westlands District, standing together before Congress, were opposed by farm, labor, and other popular organizations. This has been so for a long time, but pressures upon public officials are often severe, as the history of the excess land law demonstrates. In 1951 California Attorney General Edmund G. Brown supported his decision to press an appeal to the United States Suprenie Court from state court decisions against the excess land law, by reciting the "better than 7 to 1" popular vote in Central Valley Irrigation districts favorimg acceptance of water contracts carrying the excess land provision. (For compilation of these statistics, see 1951 Report of Special Honse Subcommittee on Irrigation and Reclamation . . . on Central Valley Project, California, as a result of hearings held Oct. 29-31, 1951, Sacramento, Cal, at 110-11 (*)). In 1958 he was eleeted Governor on a platform that reaffirmed support of the "160-acre limitation to insure equitable distribution of water and avoid the evils of land speculation and monopoly." But after election he said, in 1960 that "we can attain those just and fair ends without trying to obligate or coerce anyone to sell or divide his land in order to get water." (Address by Governor Edmund G. Brown, Califorma Water Program Bond Issue, NBC-TV and Radio Network Broadcast, Jan. 20, 1960. Wording of quotation taken from minico text of speech supplied by Office of the Governor to author, p. $4(*)$.)

An explanation has been offered for lack of firm adherence to platform and the record of popular opinion by J. Blaine Quinn, Master of the California State Grange: "We fear that it was the pressure of immense noney groups and the threat of withdrawal of financial support needed by political parties that prompted this about face." Christian Science Mouitor, March 28, 1962, p. 18, col. 5 .

128 Pound, The Limits of Effective Legal Action, 22 PA. BAR Ass'N REP. 221, 239 (1916).

127 Id. at 237.

128 Cf. Ivanloe Irr. Dist. v. McCracken, 357 U.S. 275 (1958).

129 The value of the interest-free inoney subsidy provided to irrigators by reclamation law is about $\$ 1,000$ per acre on the San Luis Federal Service Area. The benefits of circumvention of the law include not only participation in this subsidy without legal limitation, but also uncontrolled access to incremental land values accruing to permanently watered lands in the fastest growing state in the nation. The author's view has been criticised publicly by Ralph M. Brody, of Westlands Water District. Answering the author's letter to the editor of the Washington Post on July 23, 1964, entitled "Circumventing the Law," Mr. Brody dismissed the author's thesis as "part of a pattern of misrepresentations to the public and the Congress .... There is to be no 'planned' or other delivery of project water to tbose 
Enforcement fails at San Luis, not because of popular opposition, as during Prohibition, but because of concentrated and powerful opposition operating upon the law-making and law-enforcing mechanisms. The facade of official unity professed by Senator Kuchel contrasts with a remarkable alignment of popular organizations against his position, among them the AFL-CIO, National Grange, National Farmers Union, and the National Catholic Rural Life Conference. ${ }^{130}$ Lacking both effective review during legislative oversight, and official executive support, these organizations and others favoring antimonopoly water law are seriously disadvantaged in their efforts to preserve excess land law from violation. ${ }^{131}$ They face not only obstacles of cost and effort in going to court, but probleins of standing to be heard in court at all. ${ }^{132}$ More, however, than the discomfiture of private citizens unable to show the special interest necessary to obtain standing in federal court may be at stake. Judicial control of public officers becones itself uncertain. "The question we are putting," as Professor Jaffe writes, "is essentially one as to the 'necessary and proper' role of the judiciary."133 Failing practicable judi-

ineligible to receive it ... Mr. Taylor simply does not know the physical facts . . Mr. Taylor's $\$ 1000$ an acre subsidy simply does not exist." "Westlands Water Contract," Washington Post, August 29, 1964, p. A-8, col. 6.

${ }^{130}$ See also "Windfall Stirs Reaction," Sacramento Umion, Aug. 5, 1964, p. B-2, col. 6; "Conflict Over California Land," id., Aug. 9, 1964, p. C-2, col. 6. Broad popular support for the excess land law has been mamifested ever since attacks upon the application of the law in Central Valley hegan in the 1940's. See authorities cited in Taylor, Destruction of Federal Reclamation Policy? The Ivanhoe Case, 10 Stan. L. Rev. 76, 130, n.120 (1957).

131 Senator Paul Douglas pointed to a fundamental difficulty, absence of the usual participation of opposed interests in proceedings where their interests are at stake: "I think we all know the practical difficulties in sucln a situation as this. The land is owned at present by a relatively small number of persons and corporations, each one of which owns an enormous amount of land ... They are organized ... powerful ... do not wish to have their holdings broken up ... and ... can inarshal tremendous resources in support of their position and against anyone who tries to stand against them. . . Those who might benefit from the acreage limitation ... the small farmers who would come into being if the huge estates were hroken up are persons in the future ... Since they exist only in the future and not in the present, they lack voices and are in a sense unrepresented." 108 CoNG. REC. 5711 (1962). See also Taylor, supra note 31, at 501-06.

132 It slould be noted that federal law requires (44 Stat. 649 (1926), 43 U.S.C. $\$ 423$ (e) (1958)) and Califorma law permits (CAI. WATER CODE $\$ \S 22670,23225$ ) the bringing of a suit to confirm the district contract and assessments made thereunder. Availability of these suits, however, does not resolve the standing problem because typically the district sues the existing landowners ("All Persons"), and the potential landowners are still not represented. Furthermore, any independent suit by a taxpayer to vindicate the general public interest would probahly fail for lack of plaintiff's standing to raise the issue. See generally Jaffe, Standing to Secure Judicial Review: Public Actions, 74 Harv. L. Rev. 1265 (1961).

133 "The law of standing raises acute questions concerning . . . judicial control of public officers. It is accepted ... that the primary role of judicial review is the protection of interests specially affected by allegedly illegal official action . . . But when the plaintiff is not able to satisfy the requirement of special interest, when he brings his action as a repre- 
cial review, the fate of public policy lies uncertainly in the relatively uncliecked liands of often severely pressured administrative officials.

\section{$\mathrm{X}$}

\section{SACRAMENTO DIVERTERS: PATTERN OF CIRCUMVENTION}

Among recently executed agreements that show a pattern of circumvention and otherwise reflect the present intent of reclamation administration, Westlands contracts do not stand alone. Nor is legislative oversight a necessary channel to the achievement of circuinvention. With ingenuity and administrative willingness to avoid the law, varied techniques are found that accomplish the same destructive ends. Contracts executed by the Secretary of the Interior in the spring of 1964 with diverters from the Sacramento River, who have been receiving water since 1944 when Shasta Reservoir began operation, promise to prove as fatal to the excess land law as the Westlands contracts.

Glenn-Colusa Irrigation District is the largest of the water districts serving the extensive landownerships along the Sacramento River. The Glenn-Colusa contract, executed by the Secretary of the Interior in 1964, may be regarded as a prototype contract with Sacramento River diverters. Nearby is the Orland project, undertaken about 1909 under agreement with excess landholders to accept a forty-acre himitation. Contrast between Orland and Glenn-Colusa, in respect to enforcement of the excess land law and its acceptance by large landholders, could hardly be more striking.

There are about 170 Sacramento River diverters representing thousands of individual users and involving about one-half million acres using about 2.3 nillion acre-feet of water annually. ${ }^{134}$ With construction of the Central Valley Project assured in 1935, use of Sacramento River water increased rapidly. By 1951 it was three times the 300,000 acre-feet increase expected by the State of California and Reclamation officials, and "would have caused the river to be dry for about forty miles in July, 1951 if stored water had not been available from Shasta Reservoir. ..."135 Negotiations for agreement between the diverters and the Bureau of Reclamation began in 1944, but were broken off by withdrawal of the

sentative of the general public, ..." he has difficulty in obtaining standing in court to present his case as a party to a suit. Jaffe, supra note 132, at 1265 .

134 Summarization of the situation is available in a Letter From Secretary of the Interior Stewart L. Udall to Comptroller General Josepb Campbell, November 29, 1963 (*) [hereinafter cited as Udall to Campbell].

1351951 Report of Special Subcommittee on Irrigation and Reclamation . . on Central Valley Project, California, as a result of hearings held Oct. 29-31, 1951, Sacramento, Calif. at 4 . 
Bureau's offer of settlement in 1946. After a number of intervening steps, negotiations were resumed in 1961 and led to execution of contracts in $1964 . .^{193}$

The principal ineans employed in the Glenn-Colusa contract to minimize, if not totally destroy the effectiveness of the excess land law, is to give diverters an excessive allotment of Sacramento River water. Water granted by the contract is divided into "base supply" and "project supply." Neither the excess land law nor an obligation to pay the United States apply to the "base supply." Both, however, attach to the "project supply." The Secretary granted Glenn-Colusa water users "about six acrefeet per irrigable acre," or 720,000 acre-feet annually as "base supply."137 Only 75,000 acre-feet are considered to be "project supply."

Measured by several criteria, the "base supply" allotted to GlennColusa appears excessive. The approximately six acre-feet per acre granted to Glenn-Colusa District is double the California average water use per acre reported by the census, and 2.3 times the Central Valley average of 2.6 acre-feet per acre. The 75,000 acre-feet considered "project supply" in Glenn-Colusa is only 9.4 percent of total supply. Only five nonths earlier Secretary Udall advised the Comptroller General that "under the proposed agreements about thirty percent would be considered as supplied from the Central Valley Project," or more than three times this proportion. ${ }^{138}$ The 720,000 acre-feet "base supply" is about seventy percent greater than the largest pre-project diversion of 423,954 acre-feet recorded in 1943. It is about forty-two percent above the Bureau's original offer of 507,734 acre-feet made in 1944-46, based on the total of maximum inonthly diversions during the five years preceding operation of Shasta Reservoir. Leading landowners in the Glenn-Colusa district were recorded at the time as "very happy" with the original offer. ${ }^{130}$ In critical inonths the river would be dry, except for Central Valley Project. ${ }^{140}$ This dependability in water supply provided by Central Valley

136 These steps are summarized in Udall to Campbell.

137 Letter from Secretary of the Interior Stewart L. Udall to Paul S. Taylor, March 27, 1964 (*) [hereinafter cited as Udall to Taylor]. The Secretary called this allotment "not unreasonable considering the losses involved in the extensive canal system, and that rice, which uses large quantities of water, is the principal crop grown in the District." The contract grants the district the right to recapture waste, seepage and return flow waters, as does Westlands contract. Recapture of heavy return flows is customary in Glenn-Colusa.

138 Udall to Campbell. The Glenn-Colusa contract accounts for more than one-third of the total water used by Sacramento River diverters.

139 Blote to Udall. Mr. Blote was in charge of measuring diversions between 1924 and 1944, and then served the Bureau of Reclamation until 1961, first as Watermaster, then as Regional Supervisor of Irrigation and Power.

140 "An inspection of the flow records of the Sacramento River indicates that in many of the last years the Sacramento River would have been dry 50 to 60 miles above Sacramento were it not for the water released from storage at Shasta Dam." Blote to Udall. 
Project is reflected in the character of agriculture that can be practiced in the district.

A second method of weakening effectiveness of the excess land law is by substituting for the statutory prohibition that no ineligible lands shall "receive water," a "quantity-of-water" measure. This measure is to be applied, not to water received at the lands themselves, but to water delivered to the district. This administrative invention permits "averaging" by the district to the advantage of excess landloolders, in lieu of specific enforcement against ineligible lands. ${ }^{141}$

A third means of undermining the excess land law is by defining the 75,000 acre-feet "project supply" as limited to water delivered to the district only in the months of July and August. This opens opportunity to store "base supply" deliveries in June in the shallow surface basins, or reservoirs used in rice-growing, for release to ineligible lands in July or August. Surrender of United States title to waste, seepage and return flow waters within the district, which are availed of customarily on the Sacramento, is a fourth means of facilitating circumvention. ${ }^{242}$

Other, and serious objections to Glenn-Colusa contract have been made. One of these is the charge that excessive water allotments afford opportunity to sell unneeded water to others. ${ }^{143}$ Responses by the Interior Department to this charge are unconvincing. Secretary Udall said the contracts do not "provide for resale of water to municipal users."144 Assistant Secretary of the Interior Kenneth Holum rejected the criticism, saying the "contracts do not confer a water right under State law which could be used to sell surplus water."145 He added, as reassurance, that the "contract provides that no sale or disposal can be made for use out-

141 A similar device is provided in Westlands Water Service Contract, June 5, 1963, $\S 27$ (b) (ii). Martin H. Blote has said that manipulation of estimates is also encouraged. "I can see no valid basis for permitting Glenn-Colusa Irrigation District and other Sacramento River diverters to treat acreage limitations of federal reclamation law simply as arithmetical calculations, as you now do in article 19(c). Kern River interests actually acquired long ago and put to beneficial use the entire flow of the Kern River. The Corps of Engineers by their own hydrologic claims, yielded only an insignificant amount (about 50,000 acre-feet) of so-called 'new water' for agricultural purposes." Blote to Udall.

142 See text accompanying note 147 infra.

143 "In California a water right is a property right, and can be disposed of as such, and I cite sales of the Miller and Lux water rights ...." Blote to Udall.

144 Udall to Taylor. It is relevant to note that the charge is not that the contracts "provide for resale," but that they permit it.

145 Letter From Assistant Secretary of the Interior Kenneth Holum to Congressman Jeffrey Cohelan, March 31, $1964\left(^{(*)}\right.$. The contracts may not confer the water rights, but Secretary Udall spoke of "water rights" repeatedly in his description to the Comptroller General of the problem of executing contracts with Sacramento River diverters. Udall to Campbell. Attorney Martin McDonough, of the Sacramento River and Delta Water Association, praised settlement of "so vast and complicated a water rights problem without lawsuits." Sacramento Union, June 26, 1964, p. B-16, col. 1-2. 
side that [designated] area without obtaining the written consent of the United States." He failed to say that Acting Secretary of the Interior James $K$. Carr had approved a memorandum containing this statement: "Such consent has been promised to the District by means of a separate letter to be given to the [Glenn-Colusa] District at the time of execution of the proposed contract."146

Glenn-Colusa contract had not been signed two months before its circumvention of the excess land law was publicly noted. Reporting a meeting of the California Central Valley Flood Control Association, the Sacramento Union described it as "an historic compromise" between the Bureau of Reclamation and Sacramento Valley farmers, i.e., excess landholders. The "compromise . . . apparently" will see the farmers get the use of federal water without having to break up their farms. . . " The Union described some of the devices of circumvention: "The Yolo County farmers plan to use the federal water only on a 160 acre plot-but they believe the same water can be reused on other land because it does not pick up contamination from the earth in other fields." The Union added that the landholders "also expect to use ground water and other water supplies for their additional acreage and do not believe they will have to breakup their holdings."14t

Reclamation officials apparently agree with the landowners that the excess land law lias been rendered meffective by the Sacramento diverters contracts. The Union said: "Robert Pafford, director for Region Two of the Bureau of Reclamation, said that he does not believe many of the landholdings will be broken up except for some through economic factors." Referring to Westlands, the Union said "Similar contracts are also being prepared for users of San Luis Project water." The Union summed up the meaning of the Sacramento River diverters' contracts, allowing them to avoid the excess land law, in these words: "Thus a battle whicl has been waged since 1944 when Shasta Dam was built ended."148

Secretary of the Interior Udall, however, had conveyed another impression than the Sacramento Union reported, when describing the same contracts only a few months earlier in anticipation of their execution. On the eve of execution of the first Sacramento River diverters contracts he said that "when the contracts are signed" this "deplorable situation" of "taking Central Valley Project water without paying for it and without complying" with reclamation law "will be rectified."149 Rectification, it

146 Memorandum from Commissioner of Reclamation Floyd E. Dominy to the Secretary of the Interior, December 19, 1963, approved by Acting Secretary of the Interior James K. Carr, December 27, 1963.

147 Sacramento Umion, June 26, 1964, p. B-16, col. 1-2.

148 Ibid.

149 Udall to Taylor. 
appears, was accomplished with the help of two major concessions to water users: (1) by abandoning attempts "to collect now for all diversions of project water made during the past nineteen years," and (2) by agreeing to "an historic compromise" that "apparently will see" the owners of excess lands "get the use of federal water without having to breakup their farms. ..."

The Department of the Interior still insists that "no 'claims' are being "cancelled" " on the Sacramento River, and "none of the Sacramento River diverters are "being relieved of their indebtedness to the Federal Government." ${ }^{150}$ However, along the Sacramento another understanding prevails. The Sacramento Union states that "[T]he Bureau of Reclamation is offering to waive all charges for project water drawn previously by farmers if they sign a 1964 contract. The Bureau has told thirty potential signers that to get the waiver they must sign the 1964 contract."151

\section{$\mathrm{XI}$}

\section{IAW AND INSTITUTIONS: SHAMBLES}

In the long and tortuous course of circumvention of excess land law, words have been emptied of their meaning, statutes of their content, procedures of their certainty, parties of their principles, and constitutional functions of their integrity. Ethics and law lave been trampled. ${ }^{162}$ It need occasion no surprise that the question of conflict-of-interest has been raised, in both an ethical and legal sense. ${ }^{153}$ Confidence in reclamation, ${ }^{154}$ and in government as well, ${ }^{155}$ has been diminislied. ${ }^{150}$

${ }^{150}$ Assistant Secretary of the Interior Kenneth Holum to Rev. James L. Vizzard, S.J., National Catholic Rural Life Conference, July 9, $1964(*)$.

151 Sacramento Union, June 26, 1964, p. B-16, col. 1-2.

152 Russell Griffen, now chairman of Westlands Water District Board, questioned the ethics of certain Bureau officials in his testimony before the Senate Military Affairs Committee in 1944. Referring to financial contributions by westside landowners to water surveys, at invitation of officials, he said: "It seems to me that the Bureau was completely in bad faith in taking that $\$ 25,000$, knowing that they were going to support as vigorously as they lave the 160-acre limitation, knowing that our district could not accept that." Testimony Before Subcommittee on Central Valley Water Project of Senate Military Affairs Committee, San Francisco, April 7, 1944, 93. (Minueo by Bureau of Reclamation, Sacramento).

153 "Former Solicitor Bennett of Interior was counsel for the irrigators although just out of office." Letter From James G. Patton, president, National Farmers Union, to President Lyndon B. Johnson, July 29, 1964, cited at 110 Conc. Rec. 17920 (daily ed. Aug. 7, 1964). Among relevant sources are: Letter From Secretary Udall to Senator William Proxmire, September 13, $1954{ }^{(*)}$; Letter From Solicitor Frank J. Barry to Elmer F. Bennett, April 13, $1962\left(^{(*)}\right.$; Elmer F. Bennett to Solicitor Frank Barry, Jan. 26, 1962 (*) ; Udall $^{*}$ to Campbell; Letter From Campbell to Udall, Jan. 21, 1964 (*).

154 At its fortieth annual convention in St. Louis, Missouri, on Aug. 27, 1964, the National Catholic Rural Life Conference adopted a resolution stating that "if, in the very near future, there are no concrete and adequate indications of a return to effective protection 
The Federal Service Area of the San Luis unit of the Central Valley Project and the Sacramento River diverters are not the only instances of failure of the executive branch of our government to enforce the law against delivering water to ineligible lands. ${ }^{157}$ At San Luis and along the Sacramento, however, the violation is unusually dramatic in its revelation of long-calculated, substantial circumvention coming to fruition before our very eyes. To thwart legislation by exercising administrative discretion beyond tolerable limits is familiar and simple. To achieve the same ends by manipulations involving the federal executive, a state-created water district, and the Congress itself, is unusual and more complex. The former is repeated on the Sacramento. The latter is enacted at San Luis.

A final outcome fatal to law is not inevitable in either area. The Administration has been asked to investigate violation of conflict-ofinterest statutes on the Sacramento. ${ }^{158}$ Power of decision on the Federal Service Area still lies with the Executive as this Article is written. The Administration has gone so far as to ask and receive from Congress a financial appropriation to complete the circumvention, but the power of choice remains-either to continue on course and violate the law while preserving its forms, or to reverse and sustain its substance.

Subsequent to the July 8, 1964, hearings on Westlands contracts, adunimistrators have indicated they will respond to soune of the more serious attacks made upon them. Secretary Udall, for example, approved a memorandun by Assistant Secretary Holum on October 7, 1964, pro-

of the family farm and of the anti-monopoly provisions of basic reclamation law, the Conference will be forced to reconsider and to oppose any further appropriation of federal funds for reclamation projects in the Western States" (*).

155 "It seems that big money has some governmental heads of both California and the United States in the palm of their hands. Would that we had enough men in the official family of California as well as the United States who would be true to their oath of office and preserve the interests of all the people." Editorial by J. Blaine Quinn, Master, California State Grange, California Grange News, May 10, 1964, cited at 110 CoNG. REc. 17503 (daily ed. Aug. 5, 1964).

150 Some relevant questions that deserve inquiry bave not been touched upon in this Article. For example: (1) Has the Secretary of the Interior, in the Sacramento River contracts, exceeded his authority under Constitutional provisions placing navigable streams under the jurisdiction of Congress, and under $\$ 10$ of the Rivers and Harbors Act of 1890, 30 Stat. 1151 (1899), 33 U.S.C. $\$ 403$ (1958), forbidding "creation of any obstruction, not affirmatively authorized by Congress, to the navigable capacity of any ... waters"? (2) Has the Secretary exceeded law or the limits of good judgment in the Sacramento River settlements, by making piecemeal allotment of water rights to a particular interest group of irrigators, prior to broader consideration of all interests in the Sacramento River from its headwaters to San Francisco Bay, including interests in irrigation, industrial use of water, navigation, recreation, and protection from water pollution?

157 Testimony of Taylor, 1964 Westlands Hearing at 146-47.

188 See note 153 supra. 
posing important revisions in the Westlands water service contract. ${ }^{100}$ Among these are elimination of the "unavoidable" excuse clause, weighting of ad valorem taxes so as to raise the economic incentive of excess landholders to execute recordable contracts, scaling down of the share of irrigation requirements of eligible lands to be met by project water dehiveries and elevation of the share to be met by district pumping-so as to diminish the rate of ground water replenishment-and consolidation of Westlands and West Plains districts. No mention was made of an intention to make prompt request for execution of recordable contracts, or -in the alternative-iminediate designation by excess landowners of which 160 acres is to receive permitted project water.

How effectively these proposals can be carried out in negotiations between the Department of the Interior and districts representing the landowners of the Federal Service Area remains to be seen. Strict compliance by the Interior Department with the procedural requirements of the San Luis Act would mitigate the effect of pressures upon administrators to weaken enforcement of the excess land law. Will Congress insist upon exercising its power to review changes in the Westlands contracts and thereby keep the channels open to countervailing pressures from both supporters and detractors of the excess land laws? Or will the Secretary be allowed to forge clanges without resubmission for the ninety day oversight period and thereby continue the pattern of acquiescence by two branches of our federal government in what must be termed a legal and institutional shambles?

159 Amendment of water service contract, Westlands Water District, Central Valley Project, California, Memorandum from Assistant Secretary, Water and Power Development, to Secretary of the Interior, Oct. 7, 1964, in 1964 Westlands Hearing at 177-80. 


\section{California Law Review}

\begin{tabular}{lll}
\hline VoL. 52 & DECEMBER 1964 & No. 5 \\
\hline
\end{tabular}

\section{BOARD OF EDITORS}

\begin{tabular}{|c|c|}
\hline \multicolumn{2}{|c|}{$\begin{array}{l}\text { PatRICE L. SHREvE } \\
\text { Editor-in-Chief }\end{array}$} \\
\hline $\begin{array}{l}\text { EuIC ROY EISENHARDT } \\
\text { Managing Editor }\end{array}$ & $\begin{array}{l}\text { Patricr S. HobIN } \\
\text { Note \& Comment Editor }\end{array}$ \\
\hline $\begin{array}{c}\text { ELLIS J. HaRAroN } \\
\text { Article Editor }\end{array}$ & $\begin{array}{c}\text { Chardes A. BeLI } \\
\text { Note \& Comment Editor }\end{array}$ \\
\hline $\begin{array}{l}\text { THOMAS A. LEE, JR. } \\
\text { Article Editor }\end{array}$ & $\begin{array}{l}\text { DANIEI E. CUMaNINS } \\
\text { Note \& Comment Editor }\end{array}$ \\
\hline $\begin{array}{l}\text { RALPE C. WALKER } \\
\text { Research Editor }\end{array}$ & $\begin{array}{l}\text { JEROME B. FALK, JR. } \\
\text { Note \& Comment Editor }\end{array}$ \\
\hline $\begin{array}{l}\text { JANE R. BRADY } \\
\text { Book Review Editor }\end{array}$ & $\begin{array}{c}\text { DARRYL A. HART } \\
\text { Note \& Comment Editor }\end{array}$ \\
\hline
\end{tabular}

Research Board

STEPHEN R. GRANT

Robert B. Chickertic GLORIA F. DEHART JOSEPH B. GaUdeT

BARbara L. BADER D. KETTH BIITER L. Donatd Boden WIEBEE L. BUXBAUMY Loxd Paxton Derby DeNMIS M. EAGAN THEOdORE J. ENGLAND JoHn Conrad Fossum FrederICK I. FoX
Dougtas A. McGrew GoRDON H. VAN KESSEL

\section{Associates}

Frankita P. GrenN WItLIAM J. HoEse BYRON B. KOHN JAMES H. NEWHOUSE

\section{Candidates}

Gordon L. Graham KENNEY F. HEGLAND RICEARD L. JAEGER EDWIN N. LOWE, JR. WIILIAMI D. MARKENSON RoDOLFo MONTEJano GERAID E. MULLEN Charles T. Pasternack Dougras R. ReYnoLdS

Marjorie DevereuX Administrative Assistant
WATTER V. STAFFORD

DavdD C. NoLan Norman S. Oberstenn THEOdORE B. OISON
A. James Roberts III LEE Joen ScLar ROBERT W. STEDMAAN Diana S. Stoppetio Clifford K. Thompson, Jr. Michaer E. TIGAR David M. WIISON 